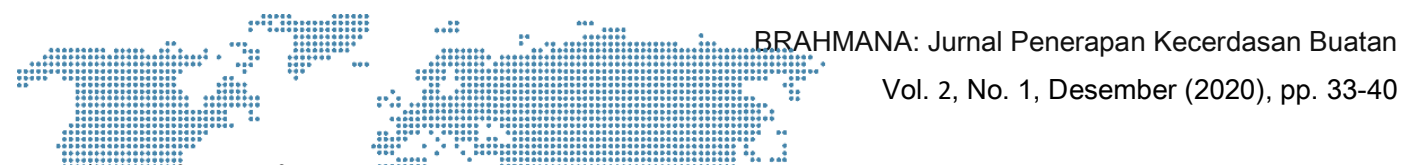

\title{
Analisa Tingkat Kepuasan Masyarakat Terhadap Pelayanan Pengadilan Agama Pematangsiantar Menggunakan Algoritma

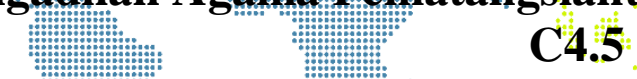

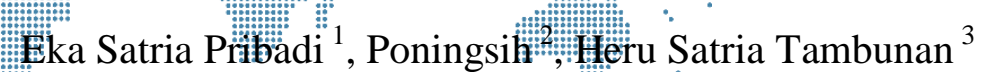

${ }^{1,3}$ STIKOM Tunas Bangsa, Pematangsiantar," Sumatera Utara, Indonesia

${ }^{2}$ AMIK Tunas Bangsa, Pematangsiantar, Sumatera Utara, Indonesia Jln. Sudirman Blok A No. 1-3 Pematangsiantar, Sumatera Utara

1ekabaladewa10@gmail.com, 2poningsih@amiktunasbangsa.ac.id,

3heru@amiktunasbangsa.ac.id

\begin{abstract}
The purpose of this study was to determine how much the level of community satisfaction with services in the Pematangsiantar Religious Court. In this study, researchers used the data mining technique C.45 algorithm. The source of research data used is by giving questionnaires to the community. In this case the researchers used the assessment attributes, among others: Service, ability, behavior, cost, and infrastructure. In this study the alternative used as a sample is Pematangsiantar City Community. the results of this study will become input for the Pematangsiantar Religious Court to provide the best possible service so that the community is satisfied with the service.
\end{abstract}

Keywords : Datamining, C4.5 Algorithm, Service Satisfaction, Religious Courts

\begin{abstract}
Abstrak
Tujuan dari penelitian ini adalah untuk mengetahui seberapa besar tingkat kepuasan masyarakat terhadap pelayanan di Pengadilan Agama Pematangsiantar. Pada penelitian ini peneliti menggunakan teknik data mining algoritma C.45. Sumber data penelitian yang digunakan adalah dengan cara memberikan angket(kuisioner) kepada masyarakat. Pada kasus ini peneliti menggunakan atribut penilaian yaitu : Pelayanan, Kemampuan, Perilaku, Biaya, dan Sarana Prasarana. Pada penelitian ini alternatif yang digunakan sebagai sampel adalah Masyarakat yang sedang melakukan sidang perkara di kantor Pengadilan Agama Kota Pematangsiantar. Hasil dari penelitian ini berupa masukan bagi Pengadilan Agama Pematangsiantar agar memberikan pelayanan sebaik mungkin sehingga masyarakat merasa puas dengan layanan tersebut.
\end{abstract}

Kata Kunci : Datamining, Algoritma C4.5, Kepuasan Pelayanan, Pengadilan Agama

\section{Pendahuluan}

Pengadilan Agama adalah pengadilan tingkat pertama yang akan melaksanakan penegakan hukum dan keadilan berdasarkan syariat islam seperti perkawinan, warisan, wasiat, hibah, zakat, infaq, shadaqah, dan ekonomi syari'ah. Adanya pelayanan dan fasilitas di Pengadilan Agama Pematangsiantar merupakan suatu tolak ukur dalam menentukan tingkat kepuasan masyarakat terhadap pelayanan yang tersedia. Dalam proses memberikan pelayanan bagi masyarakat penilaian terhadap kualitas pelayanan salah satunya didasarkan atas pengakuan atau penilaian dari pelanggan atau pihak yang menerima pelayanan. Indikator kualitas pelayanan adalah client satisfaction and perceptions, misalnya ditunjukkan dengan ada tidaknya keluhan dari pengguna jasa pelayanan. Hasil dari pengukuran kualitas akan menjadi landasan dalam membuat kebijakan perbaikan kualitas secara keseluruhan" [1].

Tingkat kepuasan masyarakat terhadap pelayanan adalah salah satu aspek penting dari fasilitas pelayanan yang diberikan sebuah instansi. Standar pelayanan 


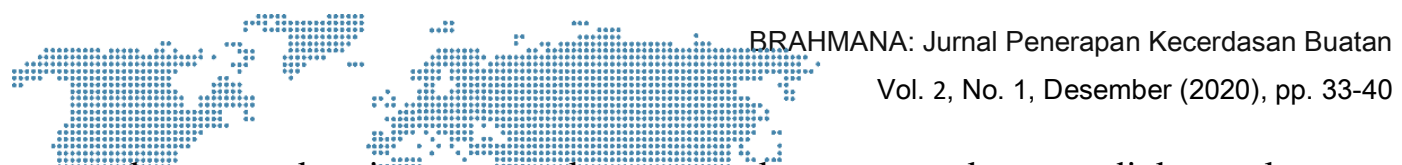

mertpakan suatu komituen penyeleng garapelayanan untuk menyediakan pelayanan dengann: suatu kualifas te tertenttullyang ditentukan atas dasar perpaduan harapan-

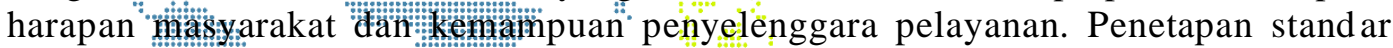
pelayanan yang dilakukan melalui proses indentifikasi jenis pelayanan, identifikasi

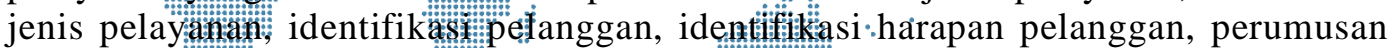
visi dan mistit pelayanan, anâlisis proses dah prosedur, sarana dan prasarana, waktu dan biaya pẹanan.

Untuk mengatasi permasalahan tersebut dilakukan sebuah penelitian dengan menggunakan Algoritma C.45 dikarenakan metode ini membuat klasifikasi lebih sederhana,mudah dan juga tingkat akurasi yang tinggi. Diharapkan penelitian ini dapat memberikan informasi kepada Pengadilan Agama Pematangsiantar dalam mengevaluasi kebijakan dan pelayanan. Penelitian ini juga diharapkan dapat memberikan masukan kepada pihak Pengadilan Agama Pematangsiantar dalam melakukan pelayanan terbaik.

\section{Metodologi Penelitian}

\subsection{Data Mining}

Data mining merupakan proses perulangan dan memerlukan interaksi manusia dalamprosesnya untuk menemukan pola atau model baru yang dapat digeneralisasi untuk masa yang akan datang, dan bermanfaat jika digunakan untuk melakukan suatu tindakan. Ada beberapa metode yang dapat digunakan dalam data mining, yaitu Association Rule, Apriori, Roughset, K-Means, Algoritma C4.5 dan yang lainlain[2][3].

Data mining disebut juga dengan Knowledge Discovery in Database (KDD) ataupun pattern recognition digunakan untuk memanfaatkan data dalam basis data dengan mengolahnya sehingga menghasilkan informasi baru yang berguna. Sedangkan istilah pattern recognition atau disebut pengenalan pola mempunyai tujuan pengetahuan yang akan digali dari dalam bongkahan data yang sedang dihadapi[4].

\subsection{Pohon Keputusan (Desicion Tree)}

Decisson tree adalah sebuah diagram alir yang mirip dengan struktur pohon, dimana setiap internal node menotasikan atribut yang diuji, setiap cabangnya mepresentasikan hasil dari atribut tes tersebut dan leaf node mepresentasikan kelaskelas tertentu atau distribusi dari kelas-kelas. Istilah Decision Tree adalah proses menemukan kumpulan pola atau fungsi-fungsi yang mendeskripsikan dan memisahkan kelas data satu dengan lainnya, untuk dapat digunakan untuk memprediksi data yang belum memiliki kelas data tertentu[5].

\subsection{Algoritma $\mathbf{C} 4.5$}

Algoritma C4.5 merupakan kelompok algoritma decision tree. Algoritma ini mempunyai input berupa training samples dan samples. Training samples merupakan data contoh yang digunakan untuk membangun sebuah tree yang telah diuji kebenarannya. Sedangkan samples merupakan field-field data yang digunakan sebagai parameter dalam klasifikasi data[6].

Secara umum langkah untuk membangun pohon keputusan Algoritma C4.5 adalah sebagai berikut [7] :

a) Pilih atribut sebagai pakar

b) Buat cabang untuk setiap nilai

c) Bagi kasus dalam cabang

d) Ulangi proses untuk setiap cabang sampai semua cabang mempunyai kelas yang sama 

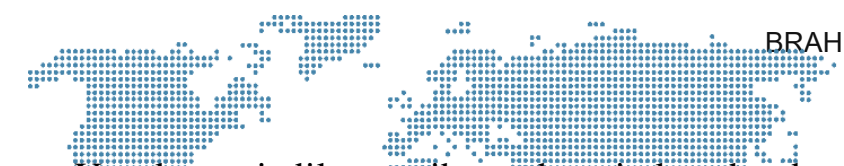

BRAHMANA: Jurnal Penerapan Kecerdasan Buatan

Vol. 2, No. 1, Desember (2020), pp. 33-40

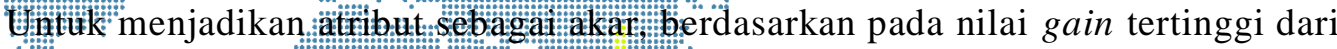

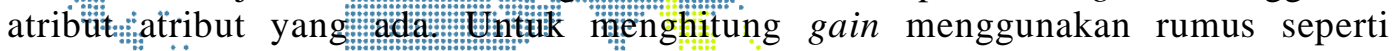

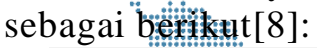

$$
\begin{aligned}
& \operatorname{Gain}(S, A)=\operatorname{Entropy}(S) \sum_{i=1}^{n} \frac{\left|S_{i}\right|}{|S|} * \operatorname{Entropy}(\mathrm{Si}) \\
& \text { Keterangam: }
\end{aligned}
$$

S : Himpunan kasus

A : Atribut

$\mathrm{n}$ : Jumlah partisi atribut A

$|\mathrm{Si}|$ : Jumlah kasus pada partisi ke i

$|\mathrm{S}|$ : Jumlah kasus dalam $\mathrm{S}$

Sebelum mendapatkan nilai gain maka dicari terlebih dahulu nilai entropy. Untuk mencari nilai entropy menggunakan rumus sebagai berikut :

Entropy $(S)=\sum_{i=1}^{n}-p i * \log _{2} p i$

$S$ : Himpunan Kasus

$\mathrm{n}:$ Jumlah partisi $\mathrm{S}$

pi: Proporsi dari Si terhadap S

\section{Hasil dan Pembahasan}

Pada penelitian ini penulis memperoleh data dari hasil kuisioner SKM (survei kepuasan masyarakat) kantor Pengadilan Agama Pematangsiantar dengan jumlah data sebanyak 150. Berikut ini merupakan data yang di peroleh dari SKM Pengadilan Agama Pematangsiantar periode Juli 2019 sampai dengan September 2019.

Tabel 1. Data Kuisioner SKM Kantor Pengadilan Agama Pematangsiantar

\begin{tabular}{|c|c|c|c|c|c|c|}
\hline No & Pelayanan & Kemampuan & $\begin{array}{c}\text { Sarana/ } \\
\text { Prasarana }\end{array}$ & Biaya & $\begin{array}{c}\text { Perilaku } \\
\text { Petugas }\end{array}$ & Keterangan \\
\hline 1 & Sesuai & Sangat Sesuai & Sesuai & Sesuai & Sangat Sesuai & Puas \\
\hline 2 & Sangat Sesuai & Sangat Sesuai & Sangat Sesuai & Sesuai & Sangat Sesuai & Puas \\
\hline 3 & Kurang Sesuai & Sesuai & Kurang Sesuai & Sesuai & Kurang Sesuai & Tidak Puas \\
\hline 4 & Sangat Sesuai & Sangat Sesuai & Sangat Sesuai & Sesuai & Sesuai & Puas \\
\hline 5 & Sesuai & Sesuai & Sesuai & Sesuai & Sesuai & Puas \\
\hline 6 & Sangat Sesuai & Sangat Sesuai & Sangat Sesuai & Sangat Sesuai & Sangat Sesuai & Puas \\
\hline 7 & Sangat Sesuai & Sangat Sesuai & Sangat Sesuai & Sangat Sesuai & Sangat Sesuai & Puas \\
\hline 8 & Sangat Sesuai & Sesuai & Sesuai & Sesuai & Sangat Sesuai & Puas \\
\hline 9 & Sangat Sesuai & Sangat Sesuai & Sangat Sesuai & Sesuai & Sangat Sesuai & Puas \\
\hline 10 & Kurang Sesuai & Kurang Sesuai & Sesuai & Sesuai & Kurang Sesuai & Tidak Puas \\
\hline 11 & Sesuai & Sangat Sesuai & Sesuai & Sesuai & Sangat Sesuai & Puas \\
\hline 12 & Sangat Sesuai & Sangat Sesuai & Sangat Sesuai & Sesuai & Sangat Sesuai & Puas \\
\hline 13 & Sesuai & Sangat Sesuai & Sangat Sesuai & Sesuai & Sangat Sesuai & Puas \\
\hline 14 & Sangat Sesuai & Sangat Sesuai & Sangat Sesuai & Sesuai & Sangat Sesuai & Puas \\
\hline 15 & Sesuai & Sesuai & Sesuai & Sesuai & Sesuai & Puas \\
\hline 16 & Sangat Sesuai & Sangat Sesuai & Sangat Sesuai & Sesuai & Sangat Sesuai & Puas \\
\hline 17 & Sangat Sesuai & Sangat Sesuai & Sangat Sesuai & Sangat Sesuai & Sangat Sesuai & Puas \\
\hline 18 & Kurang Sesuai & Sesuai & Kurang Sesuai & Sesuai & Kurang Sesuai & Tidak Puas \\
\hline 19 & Sangat Sesuai & Sangat Sesuai & Sangat Sesuai & Sesuai & Sangat Sesuai & Puas \\
\hline 20 & Kurang Sesuai & Kurang Sesuai & Sesuai & Sesuai & Kurang Sesuai & Tidak Puas \\
\hline 21 & Sesuai & Sangat Sesuai & Sesuai & Sesuai & Sangat Sesuai & Puas \\
\hline 22 & Sangat Sesuai & Sangat Sesuai & Sangat Sesuai & Sesuai & Sangat Sesuai & Puas \\
\hline$\ldots$ & $\ldots$ & $\ldots$ & $\ldots$ & $\ldots$ & $\ldots$ & $\ldots$ \\
\hline$\ldots$ & $\ldots$ & $\ldots$ & $\ldots$ & $\ldots$ & $\ldots$ & $\ldots$ \\
\hline$\ldots$ & $\ldots$ & $\ldots$ & $\ldots$ & $\ldots$ & $\ldots$ & $\ldots$ \\
\hline 145 & Sangat Sesuai & Sangat Sesuai & Sangat Sesuai & Sangat Sesuai & Sangat Sesuai & Puas \\
\hline 146 & Sangat Sesuai & Sesuai & Sangat Sesuai & Sesuai & Sangat Sesuai & Puas \\
\hline 147 & Sangat Sesuai & Sangat Sesuai & Sangat Sesuai & Sesuai & Sangat Sesuai & Puas \\
\hline 148 & Sesuai & Sangat Sesuai & Sesuai & Sesuai & Sesuai & Puas \\
\hline 149 & Sesuai & Sangat Sesuai & Sesuai & Sesuai & Sangat Sesuai & Puas \\
\hline 150 & Sesuai & Sangat Sesuai & Sesuai & Sesuai & Sangat Sesuai & Puas \\
\hline
\end{tabular}




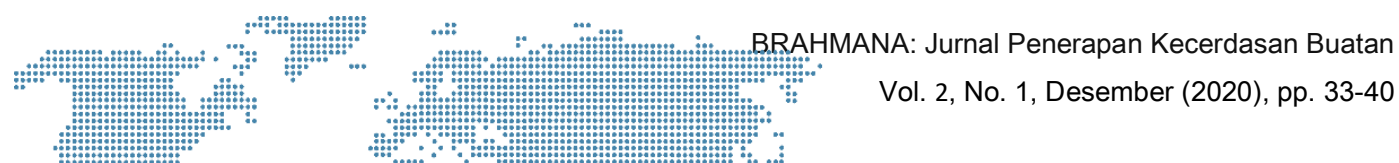

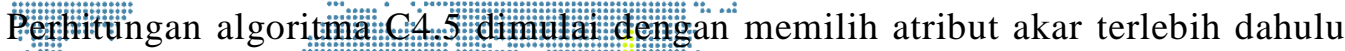

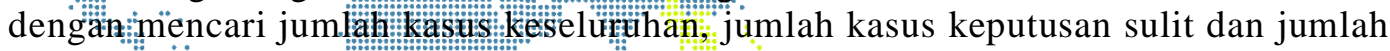
kasus kepeutusan tidâk- sutum Menghitung entrophy dari semua kasus yang dibagi berdasarkan Pelayanan, Kenampuan Petugas, Sarana/Prasarana , Biaya, dan

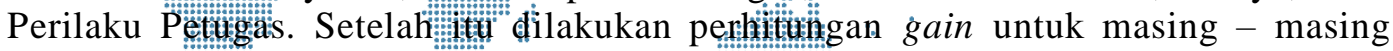

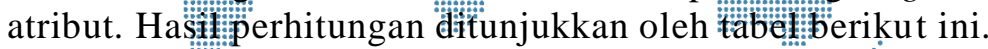

Tabel 2. Perhitungan Node 1

\begin{tabular}{|c|c|c|c|c|c|c|}
\hline & Jumlah & Puas & $\begin{array}{l}\text { Tidak } \\
\text { Puas }\end{array}$ & Entrophy & Gain \\
\hline \multicolumn{2}{|c|}{ Total } & 150 & 132 & 18 & 0,529361 & \\
\hline \multirow[t]{5}{*}{ Pelayanan } & & & & & & 0,423353 \\
\hline & Tidak Sesuai & 0 & 0 & 0 & 0 & \\
\hline & Kurang Sesuai & 15 & 4 & 15 & 0 & \\
\hline & Sesuai & 45 & 42 & 3 & 0,353359 & \\
\hline & Sangat Sesuai & 86 & 86 & 0 & 0,000000 & \\
\hline \multirow[t]{5}{*}{ Kemampuan } & & & & & & 0,457406 \\
\hline & Tidak Sesuai & 3 & 0 & 3 & 0,000000 & \\
\hline & Kurang Sesuai & 13 & 0 & 13 & 0,000000 & \\
\hline & Sesuai & 32 & 30 & 2 & 0,337290 & \\
\hline & Sangat Sesuai & 102 & 102 & 0 & 0,000000 & \\
\hline \multirow[t]{5}{*}{$\begin{array}{l}\text { Sarana/Prasar } \\
\text { ana }\end{array}$} & & & & & & 0,201299 \\
\hline & Tidak Sesuai & 0 & 0 & 0 & 0,000000 & \\
\hline & Kurang Sesuai & 12 & 4 & 8 & 0,918296 & \\
\hline & Sesuai & 57 & 47 & 10 & 0,669996 & \\
\hline & Sangat Sesuai & 81 & 81 & 0 & 0,000000 & \\
\hline \multirow[t]{5}{*}{ Biaya } & & & & & & 0,043059 \\
\hline & Tidak Sesuai & 0 & 0 & 0 & 0,000000 & \\
\hline & Kurang Sesuai & 0 & 0 & 0 & 0,000000 & \\
\hline & Sesuai & 119 & 101 & 18 & 0,612986 & \\
\hline & Sangat Sesuai & 31 & 31 & 0 & 0,000000 & \\
\hline \multirow[t]{5}{*}{$\begin{array}{l}\text { Perilaku } \\
\text { Petugas }\end{array}$} & & & & & & 0,446527 \\
\hline & Tidak Sesuai & 0 & 0 & 0 & 0,000000 & \\
\hline & Kurang Sesuai & 21 & 3 & 18 & 0,591673 & \\
\hline & Sesuai & 21 & 21 & 0 & 0,000000 & \\
\hline & Sangat Sesuai & 108 & 108 & 0 & 0,000000 & \\
\hline
\end{tabular}

Kolom entrophy pada baris total dihitung dengan persamaan (1) sebagai berikut : Entrophy $($ total $)=-(132 / 150) * \operatorname{LOG} 2(132 / 150)-(18 / 150) * \operatorname{LOG} 2(18 / 150)$

Entrophy $($ total $)=0,529361$

Kemudian pada nilai gain pada baris Pelayanan dihitung persamaan (2) sebagai berikut :

Gain $($ total,Kemampuan $)=(0,529361)-((3 / 150) * 0+(13 / 150) * 0+$ $(32 / 150) * 0,337290+(102 / 150) * 0)$

Gain $($ total,Kemampuan $)=0,457406$

Dari hasil perhitungan pada tabel 2 diperoleh atribut yang menjadi node (akar) adalah Kemampuan memiliki gain tertinggi yaitu 0,457406, dimana terdiri dari 4 sub atribut yaitu Tidak Sesuai, Kurang Sesuai, Sesuai, dan Sangat Sesuai. Berdasarkan nilai entrophy dari keempat sub atribut diatas, sub atribut Tidak Sesuai, Kurang Sesuai dan Sangat Sesuai yang Sudah memperoleh keputusan,Sedangkan Sesuai belum memperoleh keputusan. Maka perlu dilakukan perhitungan lebih lanjut 


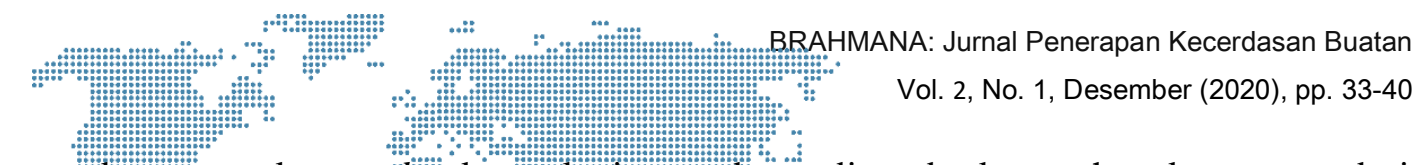

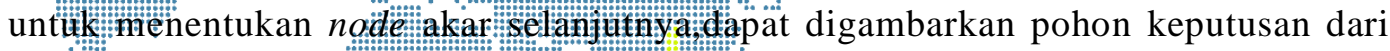

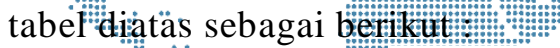

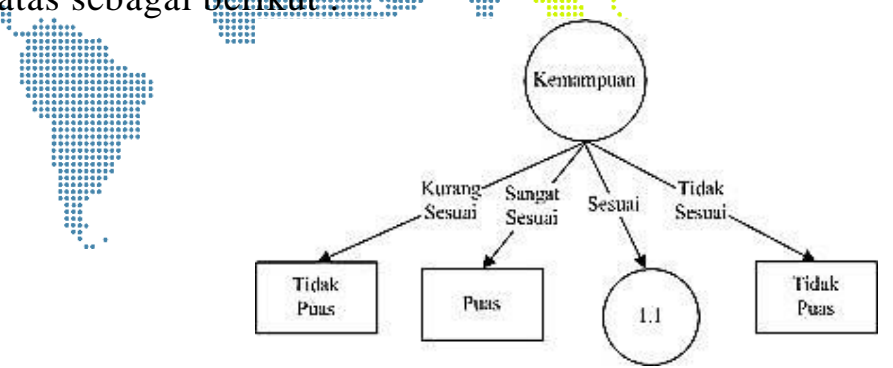

Gambar 1. Pohon Keputusan 1

Untuk hasil perhitungan selanjutnya algoritma C4.5 dapat ditunjukkan pada tabel berikut ini

Tabel 3. Perhitungan Node 1.1

\begin{tabular}{|c|c|c|c|c|c|c|}
\hline & $\begin{array}{c}\text { Jumlah } \\
\text { (s) }\end{array}$ & $\begin{array}{c}\text { Puas } \\
\text { (Si) }\end{array}$ & $\begin{array}{c}\text { Tidak } \\
\text { Puas }(\mathrm{Si})\end{array}$ & Entrophy & Gain \\
\hline \multicolumn{2}{|c|}{ Kemampuan = Sesuai } & 32 & 30 & 2 & 0,337290 & \\
\hline \multicolumn{2}{|c|}{ Pelayanan } & & & & & \\
\hline & Tidak Sesuai & 0 & 0 & 0 & 0 & \\
\hline & Kurang Sesuai & 6 & 4 & 2 & $\begin{array}{c}0,0838763 \\
89\end{array}$ & \\
\hline & Sesuai & 15 & 15 & 0 & 0,000000 & \\
\hline & Sangat & 11 & 11 & 0 & 0,000000 & \\
\hline \multicolumn{2}{|c|}{ Sarana Prasarana } & & & & & 0,228647718 \\
\hline & Tidak Sesuai & 0 & 0 & 0 & 0,000000 & \\
\hline & Kurang Sesuai & 6 & 4 & 2 & 0,918296 & \\
\hline & Sesuai & 20 & 20 & 0 & 0,000000 & \\
\hline & Sangat Sesuai & 6 & 6 & 0 & 0,000000 & \\
\hline \multirow[t]{5}{*}{ Biaya } & & & & & & 0,00601569 \\
\hline & Tidak Sesuai & 0 & 0 & 0 & 0,000000 & \\
\hline & Kurang Sesuai & 0 & 0 & 0 & 0,000000 & \\
\hline & Sesuai & 30 & 28 & 2 & 0,353359 & \\
\hline & Sangat Sesuai & 2 & 2 & 0 & 0,000000 & \\
\hline \multicolumn{2}{|c|}{ Perilaku Petugas } & & & & & 0,1651096 \\
\hline & Tidak Sesuai & 0 & 0 & 0 & 0,000000 & \\
\hline & Kurang Sesuai & 6 & 4 & 2 & 0,918296 & \\
\hline & Sesuai & 13 & 13 & 0 & 0,000000 & \\
\hline & Sangat Sesuai & 13 & 13 & 0 & 0,000000 & \\
\hline
\end{tabular}

Dari hasil perhitungan diatas pada tabel 3, atribut yang menjadi Node cabang dari atribut Kemampuan - Sesuai adalah Pelayanan. Dimana atribut dari Pelayanan yang terdiri dari Tidak Sesuai,Kurang Sesuai,Sesuai, dan Sangat Sesuai. Dimana Tidak Sesuai, Sesuai, dan Sangat Sesuai sudah memperoleh keputusan. Sedangkan untuk sub atribut Kurang belum memperoleh keputusan maka akan dilakukan perhitungan kembali. Maka dapat digambarkan pohon keputusan dari tabel diatas sebagai berikut: 


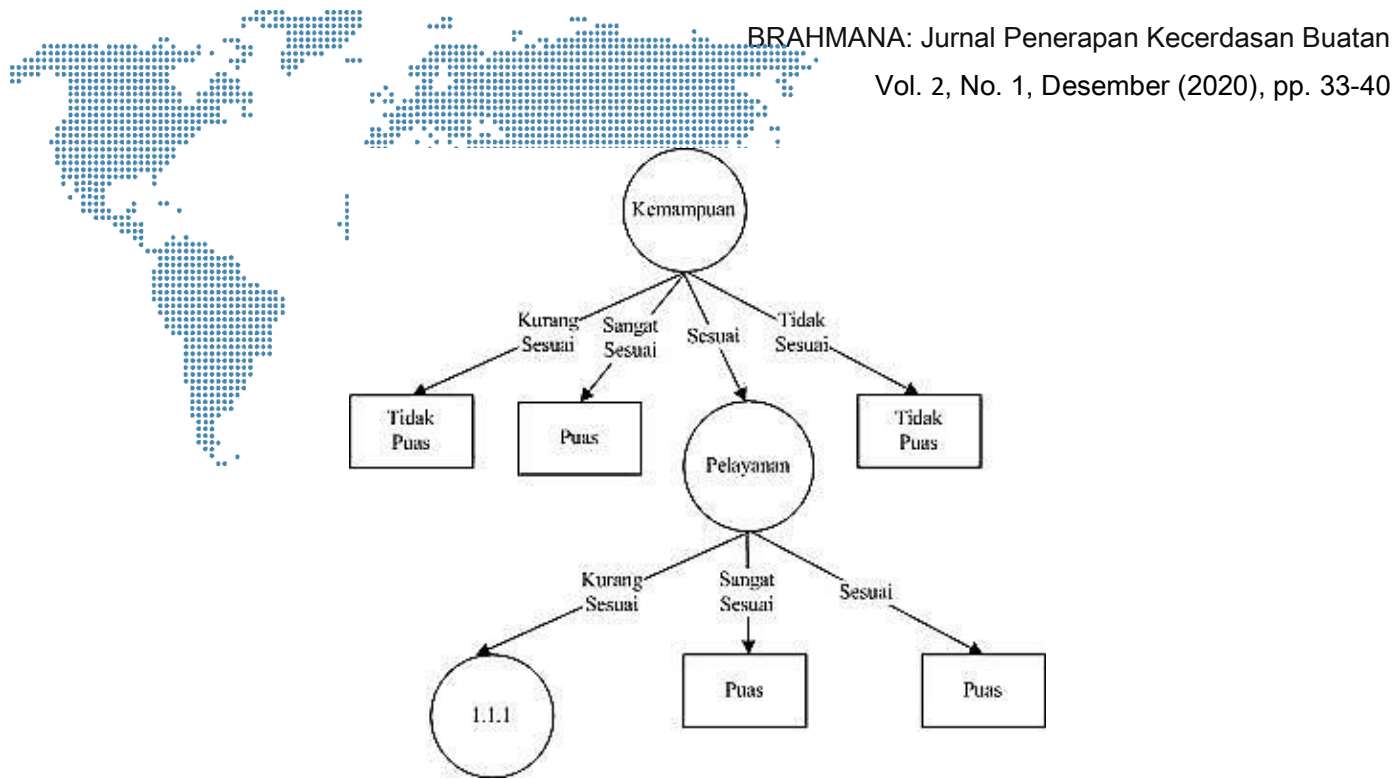

Gambar 2. Pohon Keputusan 2

Dalam mencari hasil perhitungan seanjutnya pada node akar Kemampaun-Sesuai dan node cabang Pelayanan-Kurang Sesuai hingga diperoleh hasil akhir pada node 1.1.3 dapat dilihat pada table berikut:

Tabel 4. Perhitungan Node 1.1.3

\begin{tabular}{|c|c|c|c|c|c|}
\hline \multirow{2}{*}{$\begin{array}{l}\text { Kemampuan = sesuai, } \\
\text { pelayanan = kurang sesuai, } \\
\text { Sarana Prasarana = Kurang } \\
\text { sesuai \& Biaya = Sesuai }\end{array}$} & $\begin{array}{c}\text { Jumlah } \\
(\mathrm{s})\end{array}$ & $\begin{array}{c}\text { Puas } \\
\text { (Si) }\end{array}$ & $\begin{array}{c}\text { Tidak } \\
\text { Puas (Si) }\end{array}$ & Entrophy & Gain \\
\hline & 6 & 4 & 2 & 0,918296 & \\
\hline Perilaku Petugas & & & & & $\mathbf{0}$ \\
\hline \begin{tabular}{l|l} 
Tidak Sesuai \\
\end{tabular} & 0 & 0 & 0 & 0,000000 & \\
\hline Kurang Sesuai & 6 & 4 & 2 & 0,918296 & \\
\hline Sesuai & 0 & 0 & 0 & 0,000000 & \\
\hline Tidak Sesuai & 0 & 0 & 0 & 0,000000 & \\
\hline
\end{tabular}

Dari hasil perhitungan pada tabel 4.5, atribut yang menjadi node cabang Kemampuan $=$ Sesuai, Pelayanan $=$ Kurang Sesuai, Sarana Prasarana $=$ Kurang Sesuai, dan Biaya = Sesuai adalah Perilaku petugas Dimana perilaku Petugas sudah sub atribut yaitu Tidak Sesuai, Kurang Sesuai, Sesuai dan Tidak Sesuai maka semua atribut sudah memperoleh keputusan sehingga perhitungan sudah selesai. Maka dapat digambarkan pohon keputusan dari tabel diatas sebagai berikut :

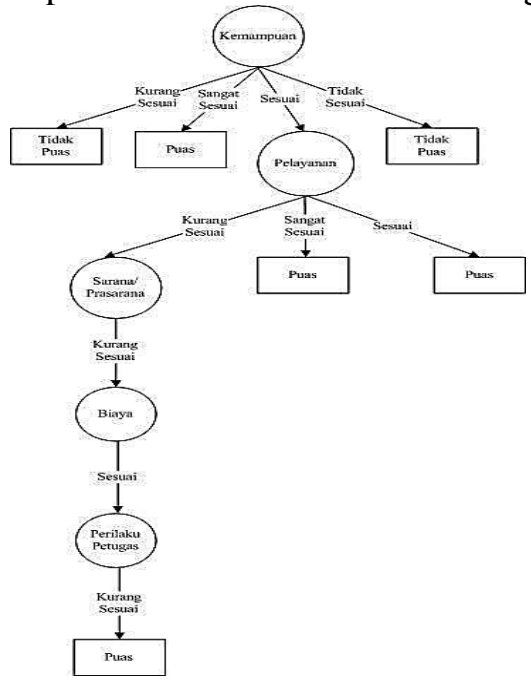

Gambar 3. Pohon Keputusan 5 


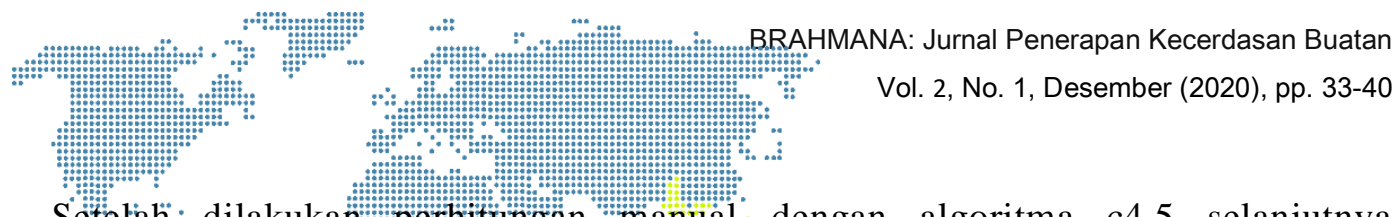

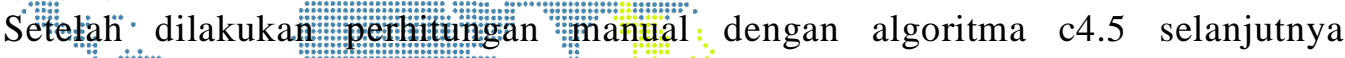

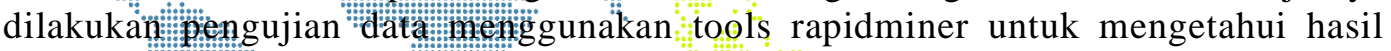
akurasi antara perhitunga man manual dengan hassil system. Berikut adalah hasil

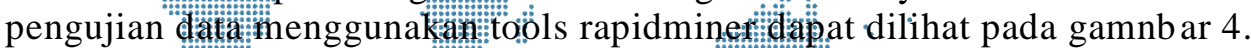

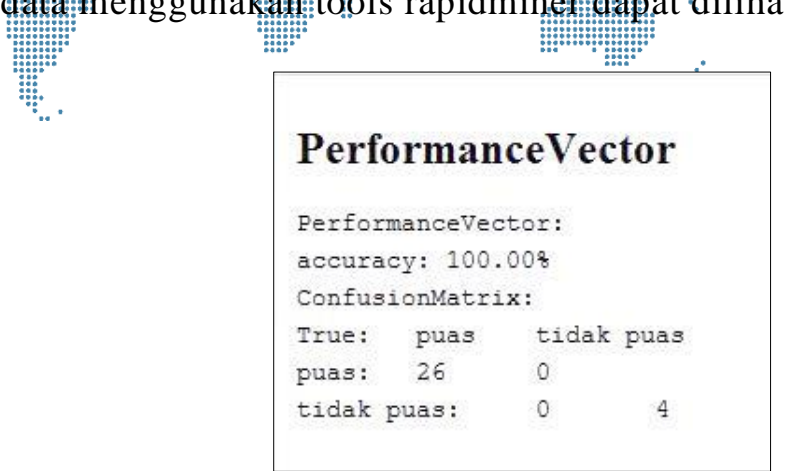

Gambar 4. Nilai Performance Vector Algoritma C4.5

Berdasarkan pengolahan data menggunakan software RapidMiner didapat nilai akurasi sistem sebesar $100.00 \%$, artinya bahwa rule yang dihasilkan tingkat kebenaran mendekati $100 \%$. Dimana model yang telah dibentuk diuji tingkat akurasinya dengan memasukan atau uji yang berasal dari data training dengan menggunakan split validation pada aplikasi rapidminer 5.3 untuk menguji tingkat akurasi.

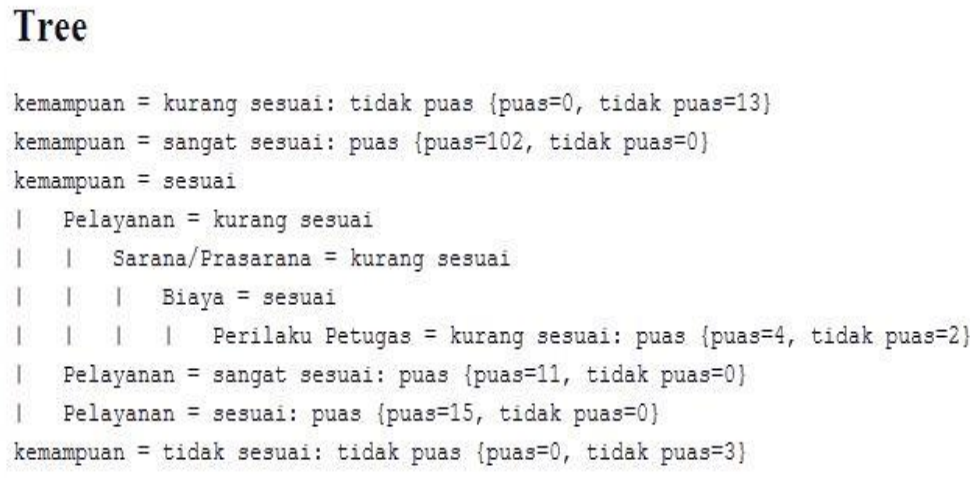

Gambar 5. Deskripsi decision tree

Gambar di atas menunjukkan hasil deskripsi secara lengkap dari pohon keputusan (decision tree) yang telah terbentuk dengan menggunakan algoritma C4.5. Dari hasil deskripsi juga menunjukkan bahwa penggunaan data mining algoritma $\mathrm{C} 4.5$ baik digunakan dalam proses menggali data (data mining process) untuk menarik beberapa kesimpulan yang divisualisasikan dengan pohon keputusan (decision tree). Berikut ini rules yang dihasilkan dari pohon keputusan tersebut :

Tabel 5. Rule yang dihasilkan

\begin{tabular}{|l|l|l|}
\hline No & \multicolumn{1}{|c|}{ Rules } & \multicolumn{1}{|c|}{ Keputusan } \\
\hline 1. & Jika Kemampuan = Kurang Sesuai & Tidak Puas \\
\hline 2. & Jika Kemampuan = Sangat Sesuai & Puas \\
\hline 3. & $\begin{array}{l}\text { Jika Kemampuan = Sesuai dan Pelayanan = Kurang } \\
\text { Sesuai dan Sarana Prasarana = Kurang Sesuai dan Biaya } \\
\text { = Sesuai dan Perilaku Petugas = Kurang Sesuai }\end{array}$ & Puas \\
\hline
\end{tabular}




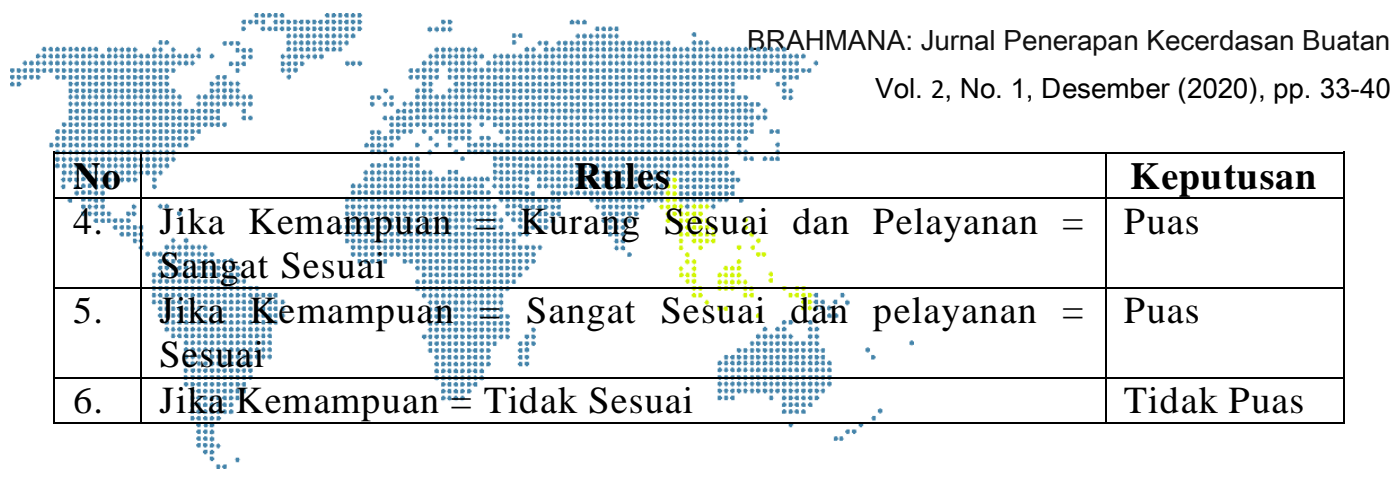

\section{Kesimpulan}

Berdasarkan seluruh hasil tahapan penelitian yang telah dilakukan pada Analisa Tingkat Kepuasan Masyarakat Terhadap Pelayanan Pengadilan Agama Pematangsiantar menggunakan Algoritma C4.5.

a) Permasalahan menganalisa tingkat kepuasan masyarakat diselesaikan menggunakan teknik data mining, yaitu dengan Algoritma C4.5. menghasilkan 6 (enam) rules dan Tingkat akurasi yang dihasilkan oleh metode tersebut adalah $100,00 \%$.

b) Dari perhitungan dengan algoritma C4.5 maka didapatkan tingkat kepuasan yang paling tinggi adalah Kemampuan Petugas (C2) dengan nilai gain sebesar 0,457406 .

\section{Daftar Pustaka}

[1] R. Mardiyanto and M. Ismowati, "Analisis Indeks Kepuasan Masyarakat Dalam Upaya Peningkatan Kepuasan Kualitas Pelayanan Masyarakat Di Kantor Kecamatan Kotabaru Kabupaten Karawang,” Vol. 9, No. September, 2017.

[2] A. S. Fristi Riandari And Song, "Penerapan Algoritma C4.5 Untuk Mengukur Tingkat Kepuasan Mahasiswa," Vol. 3, No. 2, Pp. 1-7, 2019.

[3] T. Imandasari, E. Irawan, A. P. Windarto, And A. Wanto, "Algoritma Naive Bayes Dalam Klasifikasi Lokasi Pembangunan Sumber Air," Semin. Nas. Ris. Inf. Sci., 2019, Doi: 10.30645/Senaris.V1i0.81.

[4] D. N. Batubara And A. P. Windarto, "Analisa Klasifikasi Data Mining Pada Tingkat Kepuasan Pengunjung Taman Hewan Pematang Siantar Dengan Algoritma," Komik (Konferensi Nas. Teknol. Inf. Dan Komputer), Vol. 3, No. 1, Pp. 588-592, 2019, Doi: 10.30865/Komik.V3i1.1664.

[5] A. Shiddiq, R. K. Niswatin, And I. N. Farida, "Ahmad Shiddiq Analisa Kepuasan Konsumen Menggunakan Klasifikasi Decision Tree Di Restoran Dapur Solo (Cabang Kediri)," Gener. J., Vol. 2, No. 1, P. 9, 2018, Doi: 10.29407/Gj.V2i1.12051.

[6] R. Novita, "Teknik Data Mining : Algoritma C 4 . 5," Ilmu Komputer.Com, Pp. 112, 2016.

[7] Yulia And A. D. Putri, "Data Mining Menggunakan Algoritma C4 . 5 Untuk Memprediksi Kepuasan Mahasiswa Terhadap Terhadap Kinerja Dosen Di Kota Batam Yulia , Anggia Dasa Putri," Comput. Based Informaon Syst. J., Vol. 07, Pp. 56-66, 2019.

[8] M. G. Sadewo, A. P. Windarto, I. S. Damanik, And D. Hartama, "Penerapan C4 . 5 Untuk Memprediksi Kepuasan Pasien Terhadap Sistem Informasi Manajemen Rumah Sakit ( Simrs ) Pada," Reg. Dev. Ind. Heal. Sci. Technol. Art Life, Pp. 2130, 2018. 